FACTA UNIVERSITATIS

Series: Linguistics and Literature Vol. 16, N² 2, 2018, pp. 167-180

https://doi.org/10.22190/FULL1802167P

Original Scientific Paper

\title{
THE NEOLIBERAL STATE AND THE CITIZEN IN I, DANIEL BLAKE*
}

UDC 791.233:330.831

\section{Danijela Petković}

\author{
University of Niš, Faculty of Philosophy, Niš, Serbia
}

\begin{abstract}
The paper discusses Ken Loach's critically acclaimed film, I, Daniel Blake, which, as it is argued, examines and condemns the neoliberal redefining of both the state and the citizen in contemporary Great Britain, setting this central issue in the wider, emotionally charged framework of labour, health, illness and death. The first part of the paper offers a brief, and selective, overview of current critical and theoretical thought on Anglo-American neoliberalism, state and citizenship, and summarizes the basic tenets of the recent work by Cherniavsky (2017), Brown (2015), Mirowski (2013), Wacquant (2011) and Harvey (2005) in particular. As countless other theorists and critics who further develop Foucault's (1978) insights in the $21^{\text {st }}$ century, they also agree that "the neoliberal turn" has resulted, inter alia, in a strong punitive state which nonetheless retains the outward signs and the institution of a democratic, Keynesian welfare state, including, as Loach's film demonstrates, the social services. While the critics agree that such a transformation of the state and the citizen is particularly noticeable in contemporary USA, I, Daniel Blake demonstrates that austerity-era Great Britain is not far behind.
\end{abstract}

Key words: citizen, I, Daniel Blake, Ken Loach, neoliberalism, social services, state

\section{INTRODUCTION}

In one of the chapters from Philosophy and the Politics of Animal Liberation (2016), Sue Donaldson and Will Kymlicka argue in favour of extending political rights specifically, full citizenship - to non-humans, in an attempt to counteract "the everincreasing scope and intensity of human violence towards animals" (Cavalieri 2016: 71). While the expansion of violence towards animals in the first decades of the $21^{\text {st }}$ century is

Submitted June 5, 2018, accepted for publication November 15, 2018

Corresponding author: Danijela Petković

University of Niš Faculty of Philosophy, English Department

E-mail : danijela.petkovic@ filfak.ni.ac.rs

*Prepared as a part of the project Modern Trends in Researching English Linguistics and Anglophone Literature and Culture, conducted at the University of Niš - Faculty of Philosophy (No. 183/1-16-1-01). 
unquestionable (this is not to imply that they are the only targets), Donaldson's and Kymlicka's proposition, when set against the socio-political reality of the majority of human beings at the present moment, seems oddly anachronistic. Namely, they operate with the concept of citizenship which is no longer compatible with the lived experience of large portions of the world population, including the inhabitants of the nominally democratic nation states ${ }^{1}$. Relying on "liberal egalitarian concepts of justice" (Cavalieri 2016: 106), and framing the issue of both animal rights and citizenship within the discourse of political liberalism and "grassroots democratic reform [which is] promoting opportunities for citizens to participate directly in decision-making" (Cavalieri 2016: 103) appears outdated against the reality in which the very meaning of democracy and the citizen is being radically reconfigured to signify something very far from political liberalism and its underlying humanist assumptions.

In I, Daniel Blake, the film written by Paul Laverty and directed by Ken Loach, the titular character also expresses his protest against the treatment he receives at the Newcastle Jobcentre in the language of political liberalism and modern democracy: "I, Daniel Blake, am a citizen" (Loach 2016). Moreover, the film ends with Blake's posthumous assertion of his citizenship, which further emphasizes the validity of liberal political rights. While the film was critically well-received, winning, among others, Palm D'Or at the Cannes Film Festival (2016), César Award (2016) and the British Academy Film Award for "Best British Film" (2017), the reviews have been muted on the issue of neoliberal 'citizenship'. I, Daniel Blake has been interpreted as "a declaration of personhood in the face of a system that fails to treat people with dignity" (Collins 2017), "the plea of a good man before an indifferent society" (Krauze 2017), and the criticism of "the catastrophic displacement brought on by economic and technological change" (Hornaday 2017). The central argument of this paper, however, is that Loach's film does not target merely economic and technological change which leaves necessary victims of progress in its wake. Nor does Loach merely confront the viewers with the step-by-step wasting of a human being through state-enforced 'measures', though this is certainly foregrounded. (Indeed, at the very end of the film, at Daniel Blake's funeral, his friend Katie explicitly accuses "the state" of murder, which is a much more serious accusation than "failing to treat people with dignity".) The central argument in this paper is that the film captures and condemns, from a firm liberal humanistic and democratic standpoint, a distinctive feature of $21^{\text {st }}$ century neoliberalism, the radical redefining of both the state and the citizen. Specifically, I, Daniel Blake points to the reshaping of their post-World War II, Keynesian forms: the welfare state is transformed into a punitive super-state, whereas the citizen as the bearer of "social and political rights" (Mitchell and Fazi 2017:

\footnotetext{
${ }^{1}$ Needless to say, for some portions of the population in Western democracies, Donaldson's and Kymlicka's concept of liberal citizenship, with its implications of civil and political rights and freedoms protected by the social contract, has never been compatible with the lived reality. For "the poor, the black, the unemployed" in particular, as Ambalavaner Sivanandan reminds us, "the distinction between the mailed fist and the velvet glove is a stylistic abstraction, the defining limit between consent and force a middle-class fabrication" (Sivanandan 1990: 43).

${ }^{2}$ It is important to emphasize here that although Daniel Blake is a fictional character, his struggle, as depicted in the film, is consistent with the real-life experience of the British citizens in the austerity era (cf. Frances Ryan's "Hardworking Britain" columns in The Guardian, especially "I, Daniel Blake is a realistic depiction of life on benefits. Isn't it?" https://www.theguardian.com/commentisfree/2017/feb/16/daniel-blake-realistic-life-benefits). In an interview with Liam O'Hare, Paul Laverty, too, insists on this particular aspect of his and Loach's film: “There's an absolutely vicious sanctions regime and it's been responsible for suicides, homelessness, misery, hunger; in all sorts of ways. I'm not saying this rhetorically. I've been up and down the country hearing about it first hand from people" (O'Hare 2016).
} 
166) becomes merely the human capital competing with other human capitals for economic survival. It is within this framework that other neoliberal phenomena are critically depicted in the film, from the "gig economy", into which Blake, Katie, and Blake's young neighbour China are forced; the "crisis of care" (Leonard and Fraser 2016) and "the (re)criminalization of poverty" (Peck and Tickell 2002: 391), to the highly gendered violence of said poverty and "a radical helplessness in the face of no health insurance and no clear sense of whether permanent shelter can be maintained" (Butler and Athanaisou 2013: 148). Moreover, as Daniel Blake is seriously ill, the film necessarily engages with the more general capitalist "body terrorism", which is evident in the systemic enforcement of normative able-bodied productivity (Giles 2017), and the concomitant demonization, institutional abuse and the elimination of non-productive bodies and lives. Since the primary focus of this interpretation is the film's criticism of the neoliberal redefining of the (relationship between) the state and the citizen, it is necessary to offer, first, some theoretical context on these issues.

\section{NEOLIBERALISM, THE STATE AND CITIZENSHIP}

By relying specifically on the theorists and critics who are further developing Foucault's work in the $21^{\text {st }}$ century (Oksala 2015, Brown 2015, Mirowski 2013, Cherniavsky 2017), in this paper we regard neoliberalism as nothing less than "the global force" which "infiltrates all parts of life from nation-state relationships to individual subject formation" (Pauliny 2016: xxiv). According to one of its earliest theorists, the imperative of neoliberalism is precisely "the economization of the entire social field" (Foucault 2008: 242, italics added), which is achieved by the extension and dissemination of "market rationality - cost-benefit calculation — to all institutions and social practices" (Oksala 2015), and, no less significantly, by the forced or willing internalization of said market rationality by human beings themselves. In terms of politics and governmentality, highly relevant for Loach's "citizen", neoliberalism is viewed as "a kind of political rationale producing particular kinds of subjects", while simultaneously "attack[ing] the political imagination" (Glaude 2016) - "evacuating democratic principles, eroding democratic institutions and eviscerating the democratic imaginary of European modernity" (Brown 2015: 29) in particular.

The aforementioned erosion of democratic institutions is documented at length and in excellent detail in Cherniavsky (2017), where it is argued that for several decades now there has been steady and discernible "neoliberal gravitation of capitalist states to fundamentally oligarchical and autocratic forms of government", characterized by "invasive state surveillance and the suspension of civil rights" (Cherniavsky 2017: 2). In terms of labour and social relations, neoliberalism entails the "restructuring [of] the labor process to maximize the contributions of unwaged, underwaged, or donated labor" (Bousquet 2014: 145); the simultaneous "casualisation of wage labor" (Wacquant 2011); growing corporatism; "the shift[ing] [of] the responsibilities of care from the state to the individual" (Povinelli 2012: 87). The growing demands on the workers and deteriorating working conditions are followed by specific governmental, cultural, and especially pop cultural pedagogies (Brouillette 2017), which are all centred on the "return to the idea of the moral economy [and] personal responsibility" (Medovoi 2010: 138), and the revival of the closely connected "social Darwinism, with its brutalizing indifference to human suffering" (Giroux 2004: 496). Combined, these take a tremendous toll on the newly-created precariat, which Daniel Blake represents to a certain degree. Composed of "the fractions of the post-industrial working class 
[...] bent to precarious wage-work" by "the police, courts and prison" (Wacquant 2011), the neoliberal precariat is exposed to the perpetual stress of "the arbitrary and violent rhythms of being instrumentalized as disposable labour" (Butler and Athanasiou 2013: 147). This all happens, moreover, within the framework of a strong, highly punitive neoliberal state, as $I$, Daniel Blake so clearly exhibits.

The extension of the market principles to all areas of social, political, cultural and the socalled 'private life', and the resulting destruction of the old patterns of meaning and living, are inseparable from the "novel construction of persons and states" (Brown 2015: 29). Modern power, as Foucault famously posited in Discipline and Punish, is nothing if not productive (Foucault 1979: 194). As for the new persons which, in addition to precariat, neoliberalism produces, they have been eloquently defined as homines economici - and nothing but homines economici (Brown 2015: 37). And while Lynch (2014), for instance, retains the designation "citizen" for this new construct, defining "the neoliberal citizen" as "a self-sufficient, rational and competitive, economic actor" and "a cosmopolitan [flexible] worker built around a calculating, entrepreneurial and detached self", Cherniavsky (2017: 2), writing only three years later, rightly wonders: "why we denominate this subject a 'citizen' remains unclear, since, after all, the aim of [...] neoliberal pedagogy is to dissolve the relation of subjects to governments, which has historically gone by this name".

If neoliberalism aims to dissolve citizenship as the historically specific relationship between the subject and the state, in the sense that the state no longer guarantees the majority of its citizens "security, protection, or even survival" (Brown 2015: 38), this, however, does not mean that the state itself is abolished. On the contrary, what I, Daniel Blake dramatizes so powerfully is precisely "the centrality of the state in neoliberal times" (Mayo 2011) and the significant role it plays "in propping up capital and demoting justice and citizen well-being" (Brown 2015: 41), while retaining not only outward forms of democracy (e.g. voting), but also the very institutions of the Keynesian welfare state it supersedes and dismantles ${ }^{3}$ (Lazzarato quoted in Lorey 2015). In fact, there are theorists who argue that the neoliberal state is a super-state (Wacquant 2011; Heideman 2014). As early as 1978, at the very beginning of neoliberalism as a "state project" (Peck and Tickell 2002), Foucault himself warned against conflating neoliberalism with the return to classical economic doctrines: "Neoliberalism should not be confused with the slogan 'laissez-faire,' but on the contrary, should be regarded as a call to vigilance, to activism, to perpetual interventions" (quoted in Mirowski 2013: 53).

It is this vigilance and perpetual interventions that are carried out by the neoliberal state and its institutions (including, as I, Daniel Blake demonstrates, the social services), as well as its considerable, and growing, coercive power. Wacquant (2011) employs a particularly apt metaphor of a centaur to convey the apparent paradoxes of the state's dual function under "actually existing neoliberalism":

The comparative sociology of actually existing neoliberalism reveals that it involves everywhere the building of a Centaur-state, liberal at the top and paternalistic at the bottom. Then neoliberal Leviathan practices laissez faire et laissez passer toward corporations and the upper class, at the level of the causes of inequality. But it is fiercely interventionist and authoritarian when it comes to dealing with the destructive

\footnotetext{
${ }^{3}$ In his documentary The Spirit of '45, Ken Loach examines the post-World War II creation of the welfare state in the UK, and the Thatcherite dismantling of it throughout the 1980s and 1990s.
} 
consequences of economic deregulation for those at the lower end of the class and status spectrum (italics in the original).

In a similar vein, Giroux (2004: 496) warns about the punishing aspects of the neoliberal state: "as the state is being reconfigured, it is increasingly becoming a punitive state more concerned with punishing and policing than with nurturing and investing in the public good". It is these tendencies that are clearly exemplified by the numerous scenes in the film, as we will discuss in the next section.

But if the "primary ambition of the neoliberal project is to redefine the shape and functions of the state, not to destroy it" (Mirowski 2013: 56), what is this redefined neoliberal state oriented towards? What is the purpose of the increased punishing and policing of 'citizens' that Wacquant and Giroux, as well as Loach, detect? In A Brief History of Neoliberalism, Harvey (2005: 7) discusses the emergence of the neoliberal state as an "apparatus whose fundamental mission was to facilitate conditions for profitable capital accumulation on the part of both domestic and foreign capital". Said conditions range from "set[ting] up those military, defense, police and legal structures and functions required to secure private property rights and [...] the proper functioning of markets" (Harvey 2005: 2) to the very creation of markets. "[I]f markets do not exist (in areas such as land, water, education, health care, social security, or environmental pollution) then they must be created, by state action if necessary" (Harvey 2005: 2, italics added). Unmistakably in service of (financial) capital, the contemporary neoliberal state, therefore, is a formation which is diametrically opposite to the laissez-faire doctrine and the classical liberal concepts of the state. Indeed, Brown (2015) identifies as "[o]ne of the paradoxes of the neoliberal transformation of the state" the fact that "it is remade on the model of the firm while compelled to serve and facilitate an economy it is not supposed to touch, let alone to challenge" (Brown 2015: 42).

While being in a paradoxical relationship with the economy, such a state, as previously mentioned, has considerable (and increasing) coercive power at its disposal. And it is within this framework of the state's monopoly on force, and "the linked stinginess of the welfare wing and munificence of the penal wing" (Wacquant 2011), that old phenomena such as the production of surplus population and "hypercarceration" are revived in the first decades of the $21^{\text {st }}$ century (Rehmann 2015; Lloyd and Wolfe 2016). Needless to say, the hypercarceration of the surplus population is hardly the only, or even the most conspicuous feature of the neoliberal state; however, as Loach has Daniel Blake, who is one of the dispossessed and "the unincorporable" (Lloyd and Wolfe 2016: 2), threatened with police, and finally arrested, it has been necessary to highlight this particular aspect at the expense of some others.

\section{CiTIZEN BLAKE}

I, Daniel Blake is set in the socio-economic and political landscape outlined in the abovementioned critical studies. The already bleak picture is made even bleaker by Loach's trademark filmmaking technique, his "naturalist documentary mode" (Garnham 1972: 114), or what David Archibald terms "The Loach method". The method, characterized by "location shooting, minimal use of non-diegetic music, employment of popular music [...] unobtrusive sound, natural lighting and positioning the viewer so as to create the impression that they are following the action as it unfolds before them" (Archibald 2017), complements Loach's intention for I, Daniel Blake. As Loach explains in an interview, "we wanted to do something really pared down, very economic, absolutely crystal clear [...] with a kind of raw simplicity 
because it is so strong." (Dunn 2016). While not without its ideological and political problems, this "raw simplicity" (what Sarah Street (2008: 146) accurately terms "oppositional realism") of the film is primarily mobilized for exposing the "human cost of the experiment in free market economics" (Loach quoted in Newsinger 1999). Perhaps less conspicuously, the minimalist-naturalist documentary mode is also employed to convey Loach's belief that "there are better ways to live" (Newsinger 1999), which is evident in the scenes depicting Daniel Blake's interaction with his neighbor, a young man of color nicknamed China, or with Katie and her two children. In these scenes, which function as Loach's reply to neoliberal pedagogy, the human interaction is emphatically based not on considerations of profit, but on the mutual recognition of shared humanity and the worth of another human being that is irreducible to cost-benefit calculations. The humanistic message is made even more pronounced by the shabby interiors and the non-glamourous appearance of the protagonists (another characteristic of "the Loach method" is "casting actors with characteristics similar to their roles in the film" (Archibald 2017), and Dave Johns is particularly convincing in the titular role). In one of the early scenes, for instance, one of China's roommates, while serving tea, informs Daniel Blake that they "only have one Wagon Wheel left", so he "cut it into four". In another, Daniel Blake offers gentle instructions in the art of surviving poverty to Katie's children, showing them how to make a heater out of candles and flower pots. While "celebrating working class resistance" (Newsinger 1999), these scenes also express the film's politics in an understated, minimalist way: sharing resources (food or knowledge) with others is a better way to live. This, however, is not meant to imply that sharing and solidarity should be prescribed to the members of the working class only: as The Spirit of ' 45 argues explicitly, these once were, and must again be, implemented as the principles of the socio-political and economic organization in general.

While they embody more humane and thus better ways to live, all the characters in $I$, Daniel Blake nonetheless inhabit a neoliberal super-state. Some of the abovementioned characteristics of such a socio-political and economic arrangement are easily recognized. The "casualisation of wage labour" (Wacquant 2011), for instance, is evident in China's describing his workday at the local warehouse. In a textbook example of a "leaky dialogue", China states: "Got us in at 5:30. Unloaded one truck. Guess how long that took? Forty-five minutes. And do you know how much I got paid? 3 pounds and 79 pence". Unlike China, however, who does attempt to become an entrepreneur, ultimately siding with the neoliberal redefining of a human being as "a calculating, entrepreneurial and detached self" (Lynch 2014), Daniel Blake resists numerous new pedagogies bent on producing homines economici and clings to the earlier notion of a democratic nation-state citizenship, to the extent that he even asserts it posthumously ${ }^{5}$.

Yet, the film does not end only with Blake's assertion of his citizenship, but also with the direct accusation delivered by tearful Katie (Hayley Squires): "the state drove him to an early grave". And it is the power relations between the neoliberal state and the citizen, so aptly summarized by Katie's accusation, that are in focus from the very beginning of the film. During the opening credits, there are two voices, one belonging to Daniel Blake, the other to

\footnotetext{
${ }^{4}$ In The Cinema of Ken Loach: Art in the Service of the People (2002), Jacob Leigh explains this device to which Loach and Laverty occasionally resort: "John Corner calls this kind of dialogue "leaky", in that a conversation between two people 'leaks' information to the audience in a manner he finds familiar from British wartime propaganda and documentary films" (Leigh 2002: 7).

${ }^{5}$ Subjectively, Daniel Blake is the citizen of a modern liberal democracy; objectively, he is a neoliberal citizen, i.e. a citizen only in name.
} 
Amanda, "a healthcare professional". Daniel Blake is a 59-year-old widower; the viewers learn from this dialogue that he was the one taking care of his mentally ill wife while she was dying, which calls to mind Povinelli's abovementioned comment on "the shift[ing] [of] the responsibilities of care from the state to the individual" but also Melinda Cooper's argument that the "key social unit of neoliberalism is not an individual, but the family in perpetual crisis" (quoted in Brouillette 2017). Daniel, a working-class Geordie, had been a joiner before experiencing a massive heart attack at work. Amanda is, in her own words, "a healthcare professional appointed by the Department of Work and Pensions to carry out assessments for Employment and Support Allowance", , commonly known as 'benefits'. In a polite, lilting voice, Amanda is asking Daniel Blake a series of questions - "Can you walk more than 50 meters unassisted by any other person? Can you raise either arm as if to put something in your top pocket?" - the questions Daniel has already answered, having filled in a "52-page form". The outcome of this dialogue is that, contrary to the professional opinion of his cardiologist, Daniel Blake is deemed "fit for work" by Amanda, who bases her assessment on the fact that he can walk unassisted and set the alarm clock. Consistent with the neoliberal strengthening of the state, Amanda's 'expertise', explicitly backed by it, trumps that of a cardiologist. When Daniel Blake emphasizes precisely this, asking her, "Are you a nurse? Are you a doctor?" and accusing her of working for an American company, she repeats: "I'm a healthcare professional...Our company's been appointed by the government" (italics added for emphasis). All the while, the sick man is addressed as "Mr Blake"; Amanda never raises her voice or loses her patience: the outward trappings of respect for basic human/political rights have been retained, though emptied out of any meaningful content.

Back home, Daniel phones the call centre in order to complain about the decision, as he is not fit for work (in fact, his cardiologist wants to fit him with a defibrillator, since she anticipates, correctly, another heart attack). The scene is utilized by Loach to call attention to further impoverishment of the "post-industrial working class" by the state, i.e. the creation of precariat. First, Daniel Blake is informed via a recorded message that "[ $\mathrm{t}]$ his call may incur a charge. You will be charged at the rate set by your service provider", and is then kept on hold for one hour and 48 minutes, which, as he himself notices, "will cost a fortune". One of Loach's trademark techniques, the use of popular music, is noticeable here, as Daniel Blake is kept on hold while the call centre plays Vivaldi's "Spring" on a loop. A piece of music played on a loop to a distressed person qualifies as an example of "music sadism", which, as Brauer (2016) shows, was utilized in Nazi concentration and extermination camps. While such association may not be obvious to everyone, it is arguably intended as Loach's comment on the sadistic treatment citizens receive at the hands of the punitive social services. When he is finally put through, Daniel Blake, similarly to the opening scene, is shown struggling with a disembodied male voice. The absence of a flesh and blood human being emphasizes the impersonality of the system in which people like Daniel Blake are caught; it also points to the dehumanization experienced by those who work for the system as well. The male voice informs Daniel Blake, politely, that he has scored only 12 points, "and you need 15 to obtain benefits". Daniel wants to appeal: he is informed that he can do that, but he has to "request mandatory reconsideration" first. The explanation of the forbidding phrase follows. "It means that the decision maker will reconsider it, and if he comes to the same decision, you can then appeal." However, Daniel Blake cannot request mandatory reconsideration when he wants to;

${ }^{6}$ I, Daniel Blake (2016) [film]. Directed by Ken LOACH. UK, France and Belgium: Sixteen Films et al. Italics added for emphasis. All the quotations are transcribed from the film by the author of the paper. 
first, he is told, "you must wait to get a call from the decision maker". Paul Laverty's transcribing verbatim a citizen's attempt at communication with the state reveals a recognizably Kafkaesque world of nightmarish, senseless and threatening bureaucracies. Additionally, the relationship between Daniel Blake and the much-invoked "decision maker", who remains unseen, unheard, and unapproachable, replicates, on the level of an individual life, that general movement from democracy to "fundamentally oligarchical and autocratic forms of government" Cherniavsky (2017: 2) warns against.

As he has been deemed fit for work, Daniel Blake has to apply for Jobseeker's Allowance, his sole source of income. The film examines the conditions under which he receives it in detail, as they offer further insight into the functioning of the neoliberal governmental pedagogies and the redefined role of the state as the punitive mechanism for "those at the lower end of the class and status spectrum" (Wacquant 2011). First, Daniel Blake has to continually prove that he is looking for a job, by documenting his activities in a manner that invokes both social media and secret police. Namely, he is required to regularly take pictures of himself handing out his CV to the potential employers, which results in the 'citizen' keeping himself under exceedingly normalized (self-) surveillance. Not only that, Daniel Blake has to train himself to use a computer, which he does not have nor is familiar with; to "apply online"; to type out his CV and to look for non-existent jobs on the governmentapproved site only, while being seriously ill. Most importantly, every deviation from the impossible-to-follow rules, as the film depicts in increasingly excruciating detail, leads to the dreaded word: "sanctions". The language and the institutions of both democracy and the welfare state, as Maurizio Lazzarato argues, are retained, but what the viewers witness, beyond any doubt as Loach is not subtle about it, is an apparently endless series of disciplinary acts to which "Mr Blake" is subjected: seemingly small punishments and humiliations whose cumulative effect is nothing less than death.

And it is precisely the "sanctions" that convey the punitive turn in the relationship between the neoliberal state and its 'citizens' in the clearest way. The meaning of the word is introduced via Katie, a young single mother of $\mathrm{two}^{7}$, who has just arrived from London to Newcastle. Being new to the city, she is a few minutes late for her appointment at the Jobcentre, and is immediately "sanctioned". Again, the mysterious, unnamed "decisionmaker" is invoked. When the distraught Katie, obviously familiar with the procedure, asks the Jobcentre employee if she is going to sanction her for being late, the woman replies: "I'm not going to sanction you. I'm going to refer you to the decision maker and they'll make the decision on whether they're going to sanction you'. The sanction, in this particular case, means a $40 \%$ cut in benefits, but the viewers learn later that it can also involve the freezing of payment for "the maximum of up to 3 years", effectively forcing the sanctioned 'citizen' into homelessness and food banks. Katie is left with "12 quid" in her purse, with both of her children "starting school tomorrow". When the punished woman breaks down in despair at the Jobcentre, she is accused of acting aggressively and a security guard is called to keep her in line. All the while the Jobcentre employee insists, very politely, that she "has to" refer Katie for sanction: "I have to follow the rules". Significantly, in keeping with Loach's already mentioned preference for casting actors who resemble their roles, the man playing the security guard is a policeman in real life. As Loach explains in an interview with Jamie Dunn, "he

\footnotetext{
${ }^{7}$ Darkly echoing Loach's earlier film Ladybird, Ladybird (1994), Katie, just like Maggie, has children by different fathers. Although it is not explored in the film, it is obvious that just like Maggie, Katie, too, is in danger of having her children eventually taken away from her for being an unfit mother.
} 
played it to perfection. He has the language of control while being apparently polite. 'I need you to leave for me now,' rather than just, 'Get out.' It's very passive aggressive. The aggression and the threat is there, but is done in this falsely polite way." (Dunn 2016). This underlying threat which is present in nearly every encounter between Daniel Blake, Katie, and the polite Jobcentre employees also conveys the brutality of the neoliberal centaur-state towards people who are increasingly becoming citizens (i.e. bearers of rights) only in name.

Katie's conversation with Daniel Blake (another example of a 'leaky dialogue'), which takes place after the incident with the security guard, is utilized by Loach to re-emphasize one of the key features of neoliberalism, the simultaneous hyperproduction and penalization of poverty (Wacquant 2009), which is happening to such a degree that some commentators have talked about the revival of both Elizabethan and Victorian poor laws (Cooper 2017). We learn that Katie and her children were "kicked out" of their rented flat in London. Her son Dylan's room had had "a leak coming through the wall, making him really sick." When she complained to the landlord, "he kicked us out", as the laws protecting the renters are not very precise, unlike "the rules" detailing the numerous punishable offences of the benefits-claiming poor. The three of them spent the next two years in a homeless hostel in one room, "waiting on a flat". Finally, a flat was offered - but in Newcastle. Katie left her mother in London, and came with two small children to the place where she had never been before, without any friends or other family members. The children, too, are devastated. Daisy, the daughter, "hates me", Katie says. "She had to leave her friends and her Nan". But it is not only "crisis of care" (Leonard and Fraser 2016) and the harm caused to the flesh-and-blood people by impersonal decisions that are made visible here: the state's legal and coercive apparatus is always in the background, that law which "always refers to the sword" (Rabinow 1984: 266). At this point in the film, however, Katie is still hopeful, as evidenced by her desire to plant a garden and to enrol at the Open University, "go back to the books". This hope is already being maintained by superhuman effort, in the cold apartment (heat and electricity are not provided by the kind of housing Katie and her children are given), by the young woman who has just been "sanctioned".

Daniel leaves her 20 pounds; he also starts helping her with the flat, doing whatever repairs he can, and befriending the children. As already suggested, the film positions their friendship, and the mutual care and helpfulness, against the neoliberal pedagogy which is focused on the production of isolated and competing homines economici. Daniel's and Katie's relationship exemplifies a different kind of pedagogy, summarized in Daniel Blake's letter as "look[ing] neighbor in the eye and offer[ing] help". Their mutually humanizing friendship and care, however, cannot diminish the crushing blows of the "sanctions" to which both of them are exposed as the film progresses, especially when combined with the impossibility of finding a job in the neoliberal "gig economy". Katie, caught shoplifting feminine hygiene products, resorts to prostitution in order to buy Daisy new shoes and fresh fruit for both Daisy and Dylan - she quite literally turns herself into 'human capital'. In one of the film's many difficult-to-watch scenes, Daniel finds her at her "workplace", and informs her that he has built her a bookcase, "for your books". Katie replies: "Don't show me any more love, cause it's gonna break me". In addition to the final death of the "citizen", it is this particular response by Katie that Loach employs to convey the extent of the violence of neoliberalism the most. As a humanist, Loach recognizes that violence does not take only the form of poverty and being dehumanized at the hands of the anonymous "decision makers" and the employees scared into/choosing to be loyal to "the rules": it lies precisely in the victim's explicit and apparently willing refusal of love, all the more poignant as the love being given is 
emphatically without any predatory, sexual or other, component. Loach thus employs the characters of both Daniel Blake and Katie to expose the difficulty of internalizing neoliberal imperatives, and the trauma involved in (some) people being forced, through violent and invasive state action, to reshape themselves into acceptable neoliberal subjects: entrepreneurs, 'human capitals', and homines economici surrounded by fierce business competition instead of fellow human beings. The early symbolic expression of this theme - which also summarizes the film's criticism - is found in Daniel Blake's complaint directed at Amanda: "We're getting farther and farther away from my heart".

In this paper we have been arguing that I, Daniel Blake depicts and condemns the redefined relationship between the state and the citizen under neoliberalism: the citizen as the bearer of social and political rights becomes homo economicus only; the Keynesian welfare state is transformed into the coercive apparatus for facilitating the late capitalist free-market economy. The scene which is particularly illuminating on this subject is the one in which Daniel is reproached by the Jobcentre employee for not having printed out his CV, and ordered to attend a CV writing workshop. When he tries to refuse, the employee threatens him with sanctions, insists on his written consent, and, most disturbingly, adds, "It's your choice." But Daniel Blake knows better, and he spells it out for the viewer: "No, it's not my choice. I've got no other form of income." Consent under capitalism generally, as F. Engels (1845) famously commented ${ }^{8}$, is problematic at best. But the scene highlights the function of the neoliberal Centaur-state. It is not (only) free-floating capitalism that coerces 'the citizen' - Loach has the employee remind Daniel Blake that Jobseeker's Allowance Claim... and the attending Claimant Commitment Form represent "an agreement between you and the state" (italics added). And while the term "agreement" suggests a social contract and evokes liberal democracy, what the film depicts is the very opposite of it: the viewers witness no reciprocal responsibility on the part of the state, no duty of care, only successive penalties - Giroux's "punitive state [...] concerned with punishing and policing" (Giroux 2004: 496). The CV workshop scene, moreover, unambiguously conveys that neoliberal pedagogy, just like Medovoi (2010: 138) suggests, is invested in relocating all the responsibility for survival onto the individual. Namely, the growing demands on the workers and the already outlined deteriorating working conditions are not problematized by the instructor. Instead, they are naturalized, with the roomful of (potential) employees being advised to adapt to, and thus further legitimate, inhumane working conditions. The instructor, who himself radiates exhaustion, offers them the following lesson: "You must stand out from the crowd. Get noticed. Get smart. It's not enough these days to show you have skills. You have to prove how keen you are. How dedicated." No reciprocal dedication on the part of the state or the employer is even mentioned by the instructor.

Punishing and policing, in particular, have serious implications for the neoliberal citizens' rights, freedoms and even their human status. While being called "Mr Blake"

\footnotetext{
${ }^{8}$ In The Condition of the Working Class in England (1845), Friedrich Engels compares work under capitalism with slavery, explaining that "The only difference as compared with the old, outspoken slavery is this, that the worker of today seems to be free because he is not sold once for all, but piecemeal by the day, the week, the year, and because no one owner sells him to another, but he is forced to sell himself in this way instead, being the slave of no particular person, but of the whole property-holding class". Significantly, one of the ex-miners interviewed in Loach's 2013 documentary, The Spirit of '45, reveals that, almost a hundred years after Engels's observation, the relationship between the workers and their "owners" was the same: "There's only one word to describe the coal owners. They were tyrants. They were tyrants who not only owned the mines, but they thought they owned the people who worked in the mines. And to a degree, they did".
} 
and not physically abused (though, like Katie, regularly threatened with security and police), Daniel Blake is certainly treated as a lesser human, whose choices, including the food ones, grow more and more restricted as the film progresses. In fact, it is the final sanction, the one that will explicitly force him into a food bank, that proves to be Daniel Blake's breaking point. He refuses to sign for Jobseeker's benefits, leaves the building and spray-paints "I, Daniel Blake, demand my appeal date before I starve" on the Jobcentre's facade, and squats in front of it, choosing the pose that immediately calls to mind homelessness, which is a real threat at this point, but also civil rights protests. The police is called and Daniel Blake is arrested. Through the voice of one of the rare supporters of Daniel Blake, Loach ventures the opinion that "You [the police] should be arresting the wankers who came up with the sanctions". However, bearing in mind that "[i]n the decades since the neoliberal turn, urban policing has come to play at least one of two roles: garnering municipal revenue, or policing populations left out of the 'new economy' and uncovered by the safety net" (Spence 2016), it is highly unlikely that "the wankers" will be arrested. On the contrary, it is the victims - the impoverished, the humiliated, the (rightfully) angry - who are policed, criminalized, and punished. As we hear in The Spirit of ' 45 , in the segment detailing the violent suppression of the workers' strikes under the early neoliberal Thatcher government, "The police have shown to the British people that they're not neutral when the working class decided to fight for their rights" (Loach 2013).

\section{CONCLUSION}

Daniel Blake dies minutes before his long-awaited hearing begins: the film ends with the man being given a pauper's funeral, and tearful Katie reading the letter he intended to read at the hearing. The letter gives voice to countless neoliberal 'losers', who, while victimized by the neoliberal "redistribution of wealth" (Harvey 2005: 159), and left without a state-provided safety net, are being accused of "shirking". At the same time, the letter, just like the whole film, reaffirms the liberal humanist conception of a human being, and the nation-state citizenship premised on it. Against the dehumanizing and depoliticizing neoliberal language of "clients", "customers" and "insurance numbers", Daniel Blake posthumously asserts his human and his civil status as inseparable:

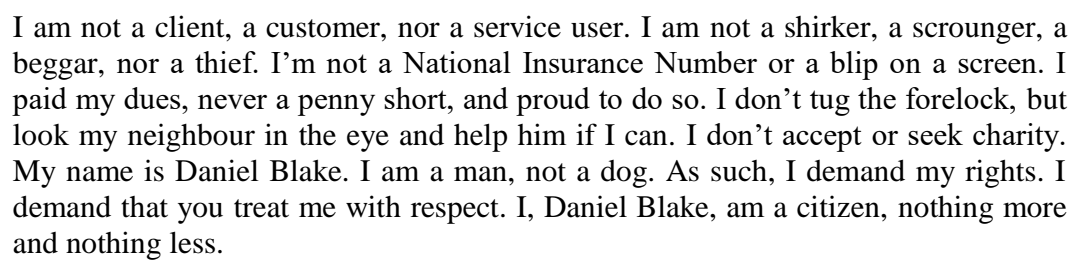

These are the last words that are heard in the film: I, Daniel Blake thus ends with the unambiguous, and anachronistic, affirmation of the modern nation-state citizenship.

Loach, however, is not blind to the anachronism. The film positions this rightsdemanding "citizen" within (and against) a neoliberal society, which is created via the neoliberal state's considerable coercive power, its legal and punitive apparatus, as well as "a new governmental pedagogy" (Cherniavsky 2017: 2), all of which are highlighted in the scenes already examined. Combined, these result in dissolving any obligation on the part of the state towards the citizens' wellbeing and, indeed, their rights, thus calling into question 
the very concept of the modern nation-state citizenship. This new society, the film demonstrates, is "an atomized society of disengaged individuals who feel demoralized and socially powerless" (Chomsky and McChesney 1999: 11); its better-adjusted members are "competitive, self-interested individuals vying for their own material and ideological gain" (Giroux 2004: 497, italics added). Politically, such redefining of the state and the citizen results - and this film depicts it in painfully naturalistic detail - in "disenfranchise[ing] peoples in many parts of the first, second, and third worlds from the prospects of selfgovernance to a degree historically unparalleled in modernity" (Brown 2004: 461, italics added). Contrary to Donaldson and Kymlicka's optimistic reading of citizenship we referred to at the beginning of the paper, I, Daniel Blake calls attention to the fact that the growing numbers of 'citizens' in Western democracies have no say whatsoever on the "issues that touch directly on their daily lives" - so directly that they, in fact, kill.

As a final point, in I, Daniel Blake, Loach is primarily interested in dissecting the statesanctioned mechanisms whereby neoliberal surplus populations are produced, disciplined and dehumanized - i.e. effectively stripped of freedom-and-rights-promising citizenship - through poverty, punishment, surveillance and policing. Yet, in keeping with his humanistic outlook, throughout the film Loach also emphasizes that the agents of "death by thousand cuts", as well as those who "help their neighbours", are other human beings. The implications of such humanism are quite rich, and potentially even political. Yet any hopefulness that may be found in the realization that human beings could choose a different path is arguably undercut by the film's conclusion, which only reinforces the unlimited punitive power of the neoliberal state $^{9}$.

\section{REFERENCES}

Archibald, D., (2017), "Revolution, My Arse”, Available at: http://eprints.gla.ac.uk/148417/1/148417.pdf [Accessed 9 Nov.2018]

Bousquet, M., (2014), "Labor", In: Burgett, B. and G. Hendler (eds.) Keywords for American Cultural Studies, NYU Press, New York.

Brauer, J., (2016), "How Can Music Be Torturous?: Music in Nazi Concentration and Extermination Camps", Music \&Politics, 10 (1), Available at: https://quod.lib.umich.edu/m/mp/9460447.0010.103/--how-canmusic-be-torturous-music-in-nazi-concentration?rgn=main;view=fulltext [Accessed 11 Nov. 2018] DOI: http://dx.doi.org/10.3998/mp.9460447.0010.103

Brouillette, S., (2017), "Couple Up: Review of "Family Values: Between Neoliberalism and the New Social Conservatism", b2o: an online journal. Available at: http://www.boundary2.org/2017/06/sarah-brouillettecouple-up-review-of-family-values-between-neoliberalism-and-the-new-social-conservatism/ [Accessed 12 March 2018]

Brown, W., (2004), “The Most We Can Hope For...': Human Rights and the Politics of Fatalism”. South Atlantic Quarterly 103(2-3): pp. 451-463; doi:10.1215/00382876-103-2-3-45

Brown, W., (2015), Undoing the Demos: Neoliberalism's Stealth Revolution, Zone Books, New York.

Butler, J. and Athanasiou, A., (2013), Dispossession: The Performative in the Political, Polity, Cambridge.

Cherniavsky, E., (2017), Neocitizenship: Political Culture after Democracy, NYU Press, New York.

Chomsky, N. and McChesney, R. W., (1999), Profit over People, Seven Stories Press, New York, Toronto and London.

Collins, G., (2017), "Review: I, Daniel Blake is a declaration of personhood", Seventh Row. Available at: https://seventh-row.com/2017/05/03/i-daniel-blake/ [Accessed 30 April 2018]

\footnotetext{
${ }^{9}$ While the film ends on a pessimistic note, this does not mean that it was not inspiring. Liam O' Hare (2016), for instance, writes that "it has repeatedly been referenced in the British parliament, described as a 'battle cry for the dispossessed' and even had its title taken up as a slogan by activists".
} 
Cooper, M., (2017), “All in the Family Debt”, Boston Review, May 31, 2017. Available at: http://bostonreview. net/class-inequality/melinda-cooper-all-family-debt [Accessed 4 March 2018]

Donaldson, S. and Kymlicka, W., (2016), "Make It So: Envisioning a Zoopolitical Revolution", In: Cavalieri, P. (ed.) Philosophy and the Politics of Animal Liberation, Palgrave Macmillan, Basingstoke and New York.

Dunn, J., (2016), "Ken Loach interview: 'I want people to be angry", The Skinny. Available at: https://www.theskinny.co.uk/film/interviews/ken-loach-i-daniel-blake [Accessed 11 Nov.2018]

Engels, F., (1845/1987), Condition of the Working Class in England. English translation. Kiernan, V (ed.). Penguin Books, New York.

Foucault, M., (1979), Discipline and Punish, Vintage Books, New York.

Foucault, M., (2008), The Birth of Biopolitics, Palgrave Macmillan, Basingstoke and New York.

Garnham, N., (1972), “TV Documentary and Ideology", Screen, 13 (2): pp: 109-115.

Giles, G., (2017), “You Do Not Exist to Be Used': Dismantling Ideas of Productivity in Life Purpose". Available at: https://thebodyisnotanapology.com/magazine/you-are-more-than-what-you-do-dismantling-ideas-ofproductivity-in-life-purpose/ [Accessed 15 May 2018]

Giroux, H., (2004), "Public Pedagogy and the Politics of Neo-liberalism: making the political more pedagogical", Policy Futures in Education, 2 (3 \& 4): pp. 494-503.

Harvey, D., (2005), A Brief History of Neoliberalism, Oxford University Press, Oxford

Heideman, P., (2014), "Bulletproof Neoliberalism", Jacobin, 06.01.2014. Available at: https://www.jacobinmag.com/ 2014/06/bulletproof-neoliberalism [Accessed 27 March 2018]

Hornaday, A., (2017), "I, Daniel Blake: A radiant portrait of resilience amid economic despair", The Washington Post, June $1^{\text {st }}, 2017$. Available at: https://www.washingtonpost.com/goingoutguide/movies/idaniel-blake-a-radiant-portrait-of-resilience-amid-economic-despair/2017/06/01/2cf18916-455f-11e7-a196a1bb629f64cb_story.html?utm_term=.4dc8cf329722 [Accessed 11 April 2018]

I, Daniel Blake (2016) [film]. Directed by Ken LOACH. UK, France and Belgium: Sixteen Films et al.

Krauze, D., (2017), "Review: I, Daniel Blake". Available at: https://www.rottentomatoes.com $/ \mathrm{m} /$ i_daniel_blake/reviews/ [Accessed 11 April 2018]

Ladybird, Ladybird (1994) [film]. Directed by Ken LOACH. UK: Channel Four Films and Parallax Pictures.

Leigh, J., (2002), The Cinema of Ken Loach: Art in the Service of the People, Wallflower Press, London.

Leonard, S. and Fraser, N., (2016), "Capitalism's Crisis of Care", Dissent Magazine. Available at: https://www.dissentmagazine.org/article/nancy-fraser-interview-capitalism-crisis-of-care [Accessed 16 April 2018]

Lloyd, D. and Wolfe, P., (2016), "Settler Colonial Logics and the Neoliberal Regime", Settler Colonial Studies, 6(2): pp:109-118. dx.doi.org/10.1080/2201473X.2015.1035361

Lorey, I., (2015), "The Precarious Minimum", The New Inquiry. Available at: https://thenewinquiry.com /the-precarious-minimum/ [Accessed 20 March 2018]

Lynch, K., (2014), "New Managerialism: The Impact on Education”, Concept, 5 (3): pp. 1-11.

Mayo, P., (2011), "The Centrality of the State in Neoliberal Times: Gramsci and beyond", International Gramsci Journal, 3: pp. 18-33.

Medovoi, L., (2010), "A Contribution to the Critique of Political Ecology: Sustainability as Disavowal", New Formations, 69: pp. 129-143.

Michael Eric Dyson vs. Eddie Glaude on Race, Hillary Clinton and the Legacy of Obama's Presidency. Available at: https://www.democracynow.org/2016/7/28/michael_eric_dyson_vs_eddie_glaude [Accessed 24 March 2018]

Mirowski, P., (2013), Never Let a Serious Crisis Go to Waste: How Neoliberalism Survived the Financial Meltdown, Verso, London and New York.

Mitchell, W. and Fazi, T., (2017), Reclaiming the State: A Progressive Vision of Sovereignty for a PostNeoliberal World, Pluto Press, London.

Newsinger, J., (1999), "Scenes from the Class War: Ken Loach and Socialist Cinema", Available at: https://www.marxists.org/history/etol/writers/newsinger/1999/xx/kenloach.htm\#n13 [Accessed 8 Nov.2018]

O'Hare, L., (2016), "When the State is Scrooge", Jacobin. Available at: https:/www.jacobinmag.com/ 2016/12/paul-laverty-i-daniel-blake-film-welfare-ken-loach/ [Accessed 12 Nov.2018]

Oksala, J., (2015), "Never Mind Foucault: What Are the Right Questions for Us?", Available at: https://itself.blog/2015/01/04/foucault-and-neoliberalism-aufs-event-johanna-oksala-never-mind-foucaultwhat-are-the-right-questions-for-us/ [Accessed 15 May 2018]

Pauliny, T., (2016), Neoliberal Rhetorics and Body Politics: Plastinate Exhibits as Infiltration, Lexington Books, Lanham, Boulder, New York and London.

Peck, J. and Tickell, A., (2002), "Neoliberalizing Space", Antipode, 34: pp. 381-404

Rabinow, P., (ed.) (1984), The Foucault Reader, Pantheon Books, New York. 
Rehmann, J., (2015), "Hypercarceration: A Neoliberal Response to 'Surplus Population", Rethinking Marxism: A Journal of Economics, Culture \& Society, 27 (2): pp. 303-311. doi.org/10.1080/08935696.2015.1007790

Ryan, F., (2017), "I, Daniel Blake is a realistic depiction of life on benefits. Isn't it?", The Guardian, 16 February 2017. Available at: https://www.theguardian.com/commentisfree/2017/feb/16/daniel-blakerealistic-life-benefits [Accessed 24 April 2018]

Sivanandan, A., (1990), Communities of Resistance: Writings on Black Struggles for Socialism, Verso, London and New York.

Spence, L., (2016), "Policing Class", Jacobin. Available at: https://www.jacobinmag.com/2016/08/baltimorepolice-department-of-justice-freddie-gray [Accessed 20 April 2018]

Street, S., (2008), British National Cinema, Routledge, London and New York.

Turcot DiFruscia, K., (2012), "Shapes of Freedom: A Conversation with Elizabeth A. Povinelli", e-flux, 53. Available at: http://www.e-flux.com/journal/53/59889/shapes-of-freedom-a-conversation-with-elizabeth-apovinelli/ [Accessed 24 April 2018]

Wacquant, L., (2009), Punishing the Poor. The Neoliberal Government of Social Insecurity, Duke University Press, Durham and London.

The Spirit of ' 45 (2013) [documentary film]. Directed by Ken LOACH. UK: BFI Film Fund.

Wacquant, L., (2011), "The punitive regulation of poverty in the neoliberal age". Available at: https://www.opendemocracy.net/5050/loïc-wacquant/punitive-regulation-of-poverty-in-neoliberal-age [Accessed 12 May 2018]

\section{NEOLIBERALNA DRŽAVA I GRAĐANIN U FILMU JA, DANIJEL BLEJK}

Rad predstavlja interpretaciju hvaljenog $i$ nagrađivanog filma reditelja Kena Louča Ja, Danijel Blejk iz 2016. godine, koji, kako u radu tvrdimo, sa pozicija liberalnog humanizma nedvosmisleno osuđuje neoliberalno redefinisanje države i građanina u savremenoj Velikoj Britaniji, postavivši ovu centralnu temu и emotivan kontekst rada, zdravlja, bolesti i smrti. U prvom delu rada dajemo kratak, $i$ selektivan, pregled modernih kritičko-teorijskih promišljanja anglo-američkog neoliberalizma, države $i$ građanstva, i sumiramo osnovne pretpostavke nedavnih studija Černiavski (2017), Braun (2015), Mirovskog (2013), Vakona (2011) i Harvija (2005). Oni se, kao i drugi teoretičari i kritičari koji u 21. veku dalje razvijaju Fukoove uvide iz 1978, slažu da je ,,neoliberalni zaokret” doveo do, između ostalog, jake punitivne države koja zadržava spoljašnje znake i institucije demokratske, kensijanske (socijalne) države. Mada se kritičari slažu da je ovakva transformacija države, i, nužno, građanina, najvidljivija danas u SAD, film Kena Louča pokazuje da ni Velika Britanija, u eri štednje, nimalo ne zaostaje.

Ključne reči: država, državne institucije, građanin, Ja, Danijel Blejk, Ken Louč, neoliberalizam. 